\title{
Types of Passive Voice Found in The Novel Say You're Sorry by Michael Robothom
}

\author{
Luh Made Giri Ratih ${ }^{{ }^{*}}$, Ni Luh Ketut Mas Indrawati ${ }^{2}$ \\ ${ }^{[12]}$ English Department, Faculty of Arts, Udayana University \\ 1'[ochan06elf@gmail.com], [2[mas.indrawati@yahoo.com] \\ *Corresponding Author
}

\begin{abstract}
This undergraduate thesis entitled Types of Passive Construction in the Novel Say You're Sorry by Michael Robotham is aimed at analyzing the types of passive voice found in the novel and figuring out which one among them is the most dominant used in the novel. The data source of this study was taken from Michael Robotham's Say You're Sorry which was published by Sphere in 2012. This study is a descriptive qualitative and quantitative research and the method used to collect the data was the documentation method using the note taking technique. The result of this study shows that there are only three types of passive voice found in the novel: be passive, get passive, and bare passive. From 219 passive sentences taken from the novel, 207 of them is be passive with the percentages of $95 \%$ while there are only 7 sentences of get passive with percentage of $3 \%$ and 5 sentences of bare passive type with the percentage of only $2 \%$.
\end{abstract}

Key words: passive voice, be passive, get passive, bare passive

\section{Abstrak}

Skripsi berjudul "Types of Passive Construction in the Novel Say You're Sorry by Michael Robotham" ini bertujuan untuk menganalisa bentuk-bentuk kalimat pasif di dalam novel serta mencari tahu bentuk pasif manakah yang paling sering digunakan. Sumber data dalam penelitian ini diambil dari novel berjudul "Say You're Sorry"karya Michael Robotham yang dipublikasikan oleh Sphere pada tahun 2012. Studi ini merupakan penelitian deskriptif kualitatif dan kuantitatif dengan metode pegumpulan data yaitu metode dokumentasi yang menggunakna tekhnik mencatat. Hasil dari penelitian ini menunjukkan bahwa hanya ada tiga betuk kalimat pasif yag ditemukan di dalam novel: pasif be, pasif get, dan pasif bare. Dari 219 kalimat pasif yang diperoleh dalam novel, pasif be terdiri dari 207 kalimat dengan persentase sebesar 95\%, sementara hanya ada 7 kalimat yang menggunakan pasif get dengan persentase $3 \%$ dan 5 kalimat yang meggunaka pasif bare dengan persentase sebesar $2 \%$.

\section{Kata kunci:Kalimat Pasif, pasif be, pasif get, pasif bare}

\section{Background of the Study}

Language (spoken or written) is a 'tool' that people use to communicate with others. The form, meaning, and context of language could be analyzed by learning the linguistic study. It incorporates a number of aspects which often include phonetics, phonology, morphology, pragmatics, semantics, and syntax. Syntax is a component of the language that interconnects words into larger units, one of which is a sentence.
A sentence could be written in active or passive voice.

A sentence is written in active. The sentence is performing the action while it could also be written in passive voice when the subject of the sentence has something done to it by someone or something.

Passive sentence could be found in many literary works including novels. In this study, a thriller novel entitled Say You're Sorry by Michael Robotham was used as the source of data to be analyzed 
in order to find more about passive voice and its types used in the novel. The novel tells a story about two friends Tash and Piper who got kidnapped and locked up for about three years by anonymous.

The topic in this study was chosen because the passive analysis on novel is rarely found and even though the use of active voice in literary works is still dominant compared with the passive voice, there are still many sentences of passive voice found in novels with different types. The study focuses on the types of passive voice clauses or sentences found in the novel Say You're Sorry by Michael Robotham and compared them to find out which types are more dominant to be found in the novel.

\section{Problems of the Study}

a) What are the types of passive voice found in the novel Say You're Sorry?

b) How does the context support the meaning and relationship between verbal and visual signs?

\section{Aims of the Study}

a) To figure out the types of passive voice found in the novel Say You're Sorry

b) To find out the percentage of each type found in the novel Say You're Sorry

\section{Research method}

Referring to the problems that already formulated, there are four components of the research method, namely: data source, method and technique of collecting data, and method and technique of analyzing data.

\subsection{Data source}

The source of data in this study was taken from Michael Robotham's Say You're Sorry, which was first published in 2012 by Sphere. This novel tells a story of the kidnapping of two best friends Tash and Piper. The whole novel was used as the data source from chapter 1 to chapter 51 consisting of 435 pages. It was chosen as the data source it is shortlisted for the CWA Gold Dagger for best crime fiction 2013and many passive sentences could be found here.

\subsection{Method and Technique of \\ Collecting data}

The data in this study were collected and selected using the documentation method through several steps. First, the data were taken by reading the content of Michael Robotham's Say You're Sorry. Second, the sentence or clauses which were in the form of passive voices were noted.

\subsection{Method and Techniques of \\ Analyzing data}

The data in this study were analyzed using the descriptive qualitative method in which all the data collected were classified and put in different tables according to the appropriate categories. The analysis of this research was based on the theory of passive voice proposed by Geoffrey Pullum (2014).

\subsection{Method and Technique of Presenting the Result of Data Analysis}

This study used the descriptive qualitative method in presenting the data. It means that the data were presented descriptively based on the theory by explaining and describing it in words or sentences through some steps as follows: first the collected data were divided in tables based on each type of passive voice. Some examples of passive voices then were taken to be analyzed and explained in chapter 3 . The percentage of each sub-type was also given in a table while the description of it was put below the table. 


\section{Results and discussions 5.1 Types of Passive be}

According to Pullum, there are seven types of passive voice. They are passive with be, prepositional passive, bare passive, embedded passive, adjectival passive, get passive, and concealed passive. However, there are only three types of passive voice found in the study; namely passive with be (Long) and (Short), Get passive and Bare passive.

\subsubsection{Passive with be}

Passive with be is a type of passive in which the main clause verb is a form of the verb $b e$, and it has a past-participial VP complement. Be passive could be analyzed based on the subject, agent, and tenses.

\section{Subject}

Nordquist (2017) stated that a subject is one of the two main parts of a sentence that usually appears before the predicate to show what the sentence is about or to know who or what performs the action. As shown below, the subject is commonly a noun, pronoun, noun phrase, or compound subject.

\section{a. Subject Pronoun}

Subject pronoun is a pronoun that takes a noun as the subject of a sentence It can be singular or plural and it can be masculine or feminine when the gender is known, but when referring to an inanimate, the gender-neutral form 'it' is used.

\section{Data 1}

He isn't fazed by police interviews because he's been here before. (Pg. 323)

Based on the sentence in data 1 , he refers to the character named Toby Kroger. In the novel, this name is already mentioned twice before the sentence such as in; "Toby Kroger sits with his legs ..." (Pg. 322) and "Kroger was kicked out of school..." (Pg. 322). In order to avoid the repetition, the name of the character is changed into he when the other characters talk about him. He itself is the third-person singular and masculine.

\section{b. Noun Subject}

Noun can act as the subject of a sentence. Noun is part of speech that could be in the form of thing, place, or names as in data 9,10 and 11 .

\section{Data 2}

... and ropes are pulled tight. (Pg. 13)

In data 2, ropes is the subject of the sentence. Ropes is a thing, length of fibers that are braided together into a stronger form.

b. NP Subject

In English grammar, a noun phrase is a word group with a noun or pronoun as its head.

\section{Data 3}

The statement is signed and dated by Probationary Constable Gerald Brindle Hughes. (Pg. 410)

\section{c. Compound Subject}

A compound subject is two or more individual noun phrases coordinated to form a single, longer noun phrase joined by and or $o r$.

In data 4, both Camera and microphone are things or nouns that are combined to form a single unit used as tools in the story in the press conference.

Data 4

Camera and microphone are positioned above. (Pg. 70) 


\section{Agent and Agentless}

In contemporary English Grammar, the agent is the noun phrase or pronoun that identifies the person or thing which initiates or performs an action in a sentence (Nordquist, 2017).

The sentence in data 5 is an example of passive voice with agent. The noun or noun phrase that would be the object of an active sentence appears as the subject of sentence or clause in the passive. The subject of a sentence or clause featuring the passive voice typically denotes the recipient of the action (the patient) rather than the performer (the agent).

\section{Data 5}

A lot of motorists were stranded by the blizzard (Pg. 22)

Contrast with passive be with agent or long passive be, in constructing passive be without agent or short passive be, the by-phrase is usually omissible. In data 6 , the subject we are chained up by someone or something that is not mentioned. One reason to make it possible is that the agent is stated in the previous sentence so it does not need to be mentioned twice.

\section{Data 6}

We were chained up in an attic room. (Pg. 5)

\section{Tense}

In the novel there are only simple present, simple past and present progressive tenses found.

\section{a. Simple Present Tense}

The simple present tense is the basic form of English tenses in which the action or event regularly takes place in present times.

\section{Data 7}

This concept of the successful psychopath is often forgotten or ignored by the medical profession. (Pg. 47)

The sentence in data 7 is the example of passive be in the present tense. It is formed with the verb to be in present tense is followed by VP forgotten and ignored. It describes or remarked the general realities that happened, how the medical profession especially the psychiatrists often ignored the issue.

\section{b. Simple Past Tense}

The simple past tense is the basic form of English tenses indicating the action or events occurring in past times.

\section{Data 8}

"Mrs. Hadley, I spoke to Hayden Mc Bain. He said that Natasha was raped and mutilated by a pedophile." (Pg. 220)

The sentence in data 8 is the example of passive be in past tense. It is formed with the verb to be in past tense was followed by the past participial of verb raped and mutilated. It describes or emphasized an event that happened in the past.

\section{c. The present progressive}

It indicates continuing action, something going on now.

\section{Data 9}

He is being questioned about those murders at the farm. (Page 83)

The sentence in data 9 is the example of passive be in present progressive tense. It is formed with the verb to be in present tense is plus being followed by the past participial of verb questioned. It indicates that the action is going on during this period and still 
happens at this moment; it is mentioned by the character in the novel.

\subsubsection{Get Passive}

In the get-passive, the subject receives the action of the verb in the form of get plus a past participle.

\section{Data 10}

Aiden got wasted at the party (Pg.188)

Seeing the sentences above, the get passive is normally constructed with human subject that is non-agentive, affected. It emphasizes more on the subject and on what happens to the subject as a result of the event rather than the agent. It emphasizes the subject referent's condition which is usually on unfavorable conditions just like got sent to see the headmistress and got wasted at the party. The events that are perceived are either having fortunate or unfortunate consequences for the subjects.

\subsubsection{Bare Passive}

We can have passive with no auxiliary verb at all. They are called bare passives because they are kinds of naked without their auxiliary verb and cannot be put into tenses form.

\section{Data 11}

She leads me upstairs, pausing at the open door to Emma's room where we watch our youngest sleeping, surrounded by stuffed animals and her gloriously imaginative paintings. (Pg. 434)

The passive clause above only consists of subject preceded by by and the past participle of a verb. The subject of the clause is our youngest followed by by phrase and past participle surrounded. It doesn't contain be (was, were) as it does in passive with be but we know that the clause implies the same meaning as it has in our youngest are surrounded by.

\subsection{The Percentages of Passive Voice Types in the Novel Say You're Sorry by Michael Robotham}

The Percentages of Passive Voice Types in the Novel Say You're Sorry by Michael Robotham are given in the table below:

\begin{tabular}{llcl}
\hline No & $\begin{array}{c}\text { Sub- } \\
\text { types }\end{array}$ & Numbers & Percentages \\
\hline 1 & $\begin{array}{l}\text { Be- } \\
\text { passive }\end{array}$ & 207 & $95 \%$ \\
2 & $\begin{array}{l}\text { Get- } \\
\text { passive }\end{array}$ & 7 & $3 \%$ \\
3 & $\begin{array}{l}\text { Bare } \\
\text { passive }\end{array}$ & 5 & $2 \%$ \\
\hline
\end{tabular}

The table above shows that there are 207 sentences that used be passive structure, so it is more dominant than the other types of passive voice. While Bare passive had the least number used in the novel.

\section{Conclusion}

According to Pullum, there are seven types of passive voice. They are passive with be, prepositional passive, bare passive, embedded passive, adjectival passive, get passive, and concealed passive. However, there are only three types of passive voice found in the study, namely passive with be (Long) and (Short), Get passive and Bare passive.

From 219 passive sentences found in the novel, be passive is more dominant used in the novel with a percentage of $95 \%$ while bare passive type is the least used among others with only a percentage of $2 \%$. 


\section{References}

Pullum, Geoffrey K. Fear and Loathing of the English Passive. 2014.Available online on http://www.sciencedirect.com/science/a rticle/pii/S0271530913000980

Quirk, Randolph et al. 1985. A Comprehensive Grammar of the English Language. New York: Longman.

Nordquist, Richard. "Agents in English Grammar." ThoughtCo, Jun. 1, 2017, thoughtco.com/what-is-agentgrammar-1689073.

Robotham, Michael. 2012.Say You're Sorry.Great Britain: Sphere 